\title{
The Impact of Employee Turnover on Organizational Performance: A Case Study of Mada Walabu University, Bale Robe, Ethiopia
}

\author{
Dejene Taye $^{{ }^{*}}$ and Bamlaku Getnet ${ }^{2}$ \\ ${ }^{1 \& 2}$ Department of Environmental Science, School of Natural Science, Madawalabu University, Bale Robe, Ethiopia. \\ *Correspondence: dejene.taye@ mwu.edu.et
}

\begin{abstract}
This research focuses on the impact of staff turnover on organizational effectiveness and performance in Mada Walabu University. High staff turnover rates may jeopardize efforts to attain organizational objectives. In addition, when an organization loses a critical employee, there is a negative impact on innovation, consistency in providing service to primary users may be jeopardized and major delays in the delivery of services to customers may occur. The research design used in this study was the descriptive approach, which allowed the researcher to use semi-structured questionnaires when collecting data. The survey method used in this study because the target population only composed of 425 employees. The study employed Purposive, Simple Random sampling and Convenience sampling techniques. A high response rate of $100 \%$ obtained using the personal method of data collection; questionnaire structured in a 5-point Likert scale format. Furthermore, the study interviewed human resource head and ten voluntary employees by convenient sampling techniques. The study finding suggests that high labor demand and job opportunities in the market, lack of opportunity for career advancement in the organization, Unsatisfied with working condition and no involvement in decision-making, are the foremost causes of employee's turnover on organizational performance. The study finding also showed that staff turnover causes loss of some of the very experienced and skilled employees, reduction in work productivity and quality of services rendered as well as it causes too much wastage of resources when new staff settles and lose public confidence in the operation of the organization. In order to return the reduced university's capacity in terms of national attrition rates, higher education access target, quality education assurance, significant community and technology transfer and standardized research-based problem-solving culture due to staff turnover.
\end{abstract}

Keywords: Employee, Impact, Turnover, Mada Walabu University, Performance, Ethiopia, and Academic staffs.

\section{INTRODUCTION}

In this world of globalization there are growing changes and challenges in the society in which we leave and in which our work organizations operate. There are also growing changes and challenges taking place inside work organizations themselves. These changes and challenges are having an impact upon the

UniversePG I www.universepg.com management of people in work organization and the performance of these organizations on the one hand and upon the environment in which work organization must exist on the other hand (Ngirwa, 2005). Labour turnover is one of the challenges that faced the work organization and have impact in the performance of those organizations. The concept of employee turnover represents one of the themes in the analysis of the 
world of work among scholars in the field of management, organization behavior, and human psychology. It refers to the process whereby employees leave the organization. It can also be referring as a degree of individual movement across the membership boundary of a social system (Hammermesh and Rees, 1984). According to Muhammad; Employee turnover in organization is one of the main issues that extensively affect the overall performance of an organization (Ubagu and Gbuushi, 2020). It is often suggested that organization should be adopt the clear Standard Operation Procedures (SOP's) that decrease the gap among the top management and the middle management in order to identify and resolve the issue of employee turnover in the organization (Muhammad et al., 2013).

The Ethiopian Government has the vision of vastly increasing the numbers of students within HEIs and increasing the numbers of universities and university colleges in the country. It intends to simultaneously expand the intake of the existing higher institutions and open 12 new university colleges within the same, short, timescale as well as ensuring quality of education. But Ethiopian universities suffer a shortage of academic staff. It is estimated that $70 \%$ of faculty in the new universities are only qualified to bachelor degree level. The government is trying to overcome the problem of the chronic shortage of qualified academic staff by establishing a massive Programme of in-country provision of masters and $\mathrm{PhD}$ programmer, supported by the more established universities in the country and foreign universities (MoE, 2003).

Meanwhile, university managers are challenged to find non-monetary means to reward staff, such as motivational strategies and staff turnover. In higher education institutions, the importance of academics for quality education is indispensable. The members of the academic staff are central to the successful accomplishments of the missions and responsibilities mandated to higher education institutions and goals set to be achieved by them (Altbach, 2006). As to Stromquist (2007), professors are central actors in higher education institutions, mainly because they are the ones who engage in the knowledge production and transmission that constitute the central and prior missions of such organizations. Moreover, results of empirical studies conducted by different researchers (Ayalew, 2007; Brook, 2007; and Demissu, 2007; Habtamu, 2007; Tesfaye, 2007; Teshome, 2007; Wana, 2007) revealed that due to insufficient salaries the academic staff in public universities of Ethiopia are forced to engage in private consultancy or extra teaching to supplement their insufficient salaries. According to the research conducted in 10 agricultural colleges, $82 \%$ of employees in the colleges have an intention to leave their current job. Thus, the efficiency and performance of public universities of Ethiopia in general and Madda Walabu University in particular are highly affected by employee turnover. To achieve mission and vision of the university, many have been sent to short- and long-term training program either in the country or abroad for masters and PhD Degrees. On the other hand, unless organizations retain workers for a reasonable period, they are unlikely to be able to provide the quality services required to remain competitive. Fast turnover of academicians affects both the faculties and the university. For faculty members that leave their employment, it cannot be easy to learn new job specific skills and find different career prospects. Universities will also lose jobspecific skills, which will be disruptive to their teaching/learning, as well as to their service rendering processes. Subsequently, fast turn-over of faculty increases the cost that the universities incur in their human resources development activities (Hailu et al., 2013).

Beside of limited impact turnover study at faculty level in this institution and high Governmental focus area of Strategy; the impact of employees' turnover on the organizational performance in Madda Walabu University is being one area of study to narrow the gap of the problem. Therefore, to minimize the impact of employees' turnover on organizational performance, it is necessary to analyze the trend of employees' turn over across years is a pillar in achieving such desired strategies of the country in general and minimizing the effects of turnover of the institution in particular. In this perspective, the researcher intends to examine the impact of employees' turnover on organizational performance in case of Madda Walabu University. 
Hence, this study focuses on the impact of employees' turnover on the organizational performance in Madda Walabu University. The University is one of the recently founded (1997E.c) institutions of public higher education in the Ethiopia. However, Madda Walabu University makes an effort on training of employees, because of multiple reasons educated and skilled employees of the University are leaving their job and join other similar institutions or other organizations these have an ultimate impact on organizational performance. Therefore, the purpose of this study is to investigate impact of employees' turnover on organizational performance of Madda Walabu University.

\section{Objectives of the Study}

The general purpose of this study is to investigate the impact of employees' turnover on organizational performance specifically in Madda Walabu University. The Specific objectives of the study are -

$>$ To analyze major factors that leads to employees' turnover in Madda Walabu University.
$>$ To assess the availability of retention strategies adopted by Madda Walabu University.

$>$ To analyze the trend of employees', turn over across years (2010-2015).

$>$ To identify the effect of employees' turnover on performance of Madda Walabu University.

\section{Conceptual Framework}

Hence, to frame the above research questions the study used the following conceptual frame work to show what are the effects of turnover on performance of Mada Walabu University as reviewed from different literatures? According to Carrel et al. (2000), staff turnover may be caused by Employee Expectations, High Labor Demand, Individual Employee, Job Ownership, Physical Environment, Poor Employee Orientation, Work Content, Lack of Staff Involvement, Trust and Confidence in Senior Leader, low remuneration, job dissatisfaction and unfair treatment. Staff turnover costs may be estimated to include separation, replacement, recruitment and training costs. Thus, if management were aware of the causes of staff turnover, they could try to resolve them.

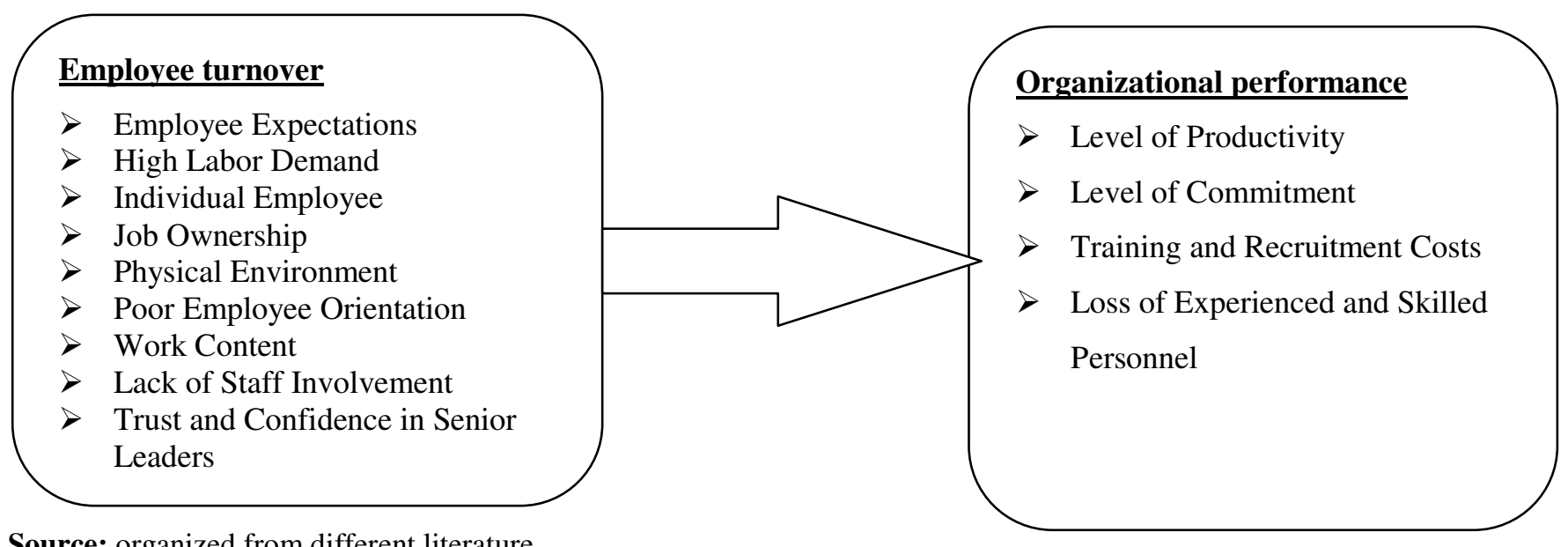

Source: organized from different literature

Fig 1: Conceptual framework relating employee turnover and Organizational performance.

Additionally, labor turnover is costly and unproductively time consuming, and it is responsible for the early cycle of recruitment employment orientation production, resignation that is detrimental to the reputation of organizations which are entangled in it (Henry, 2007).

UniversePG I www.universepg.com

\section{Operational Terms}

Academic staffs in this study refer all employees (except medical Science and foreign academic staff) whose primary assignment is instruction, research, or public service. Employee turnover is to mean the rotation of workers around the labor market, between firms, jobs and occupations, and between the states of 
employment that can occur in any organization might be either voluntary or involuntary. But this study considers only voluntary turnover which occurred when an employee leaves by choice (Mathis and Jackson, 2006).

\section{Description of the Study Area}

The study is conducted in Mada Walabu University which is one of the recently founded (1997E.c) institutions of public higher education in the Ethiopia and is located in south eastern Ethiopia, Bale Zone at robe about $430 \mathrm{~km}$ away from the capital city of the Country. For the purpose of this study, only academic staff of the university is considered. Therefore, the target population of the study is 595 academic staff who is on duty in robe campus of which 425 are local academic staff.

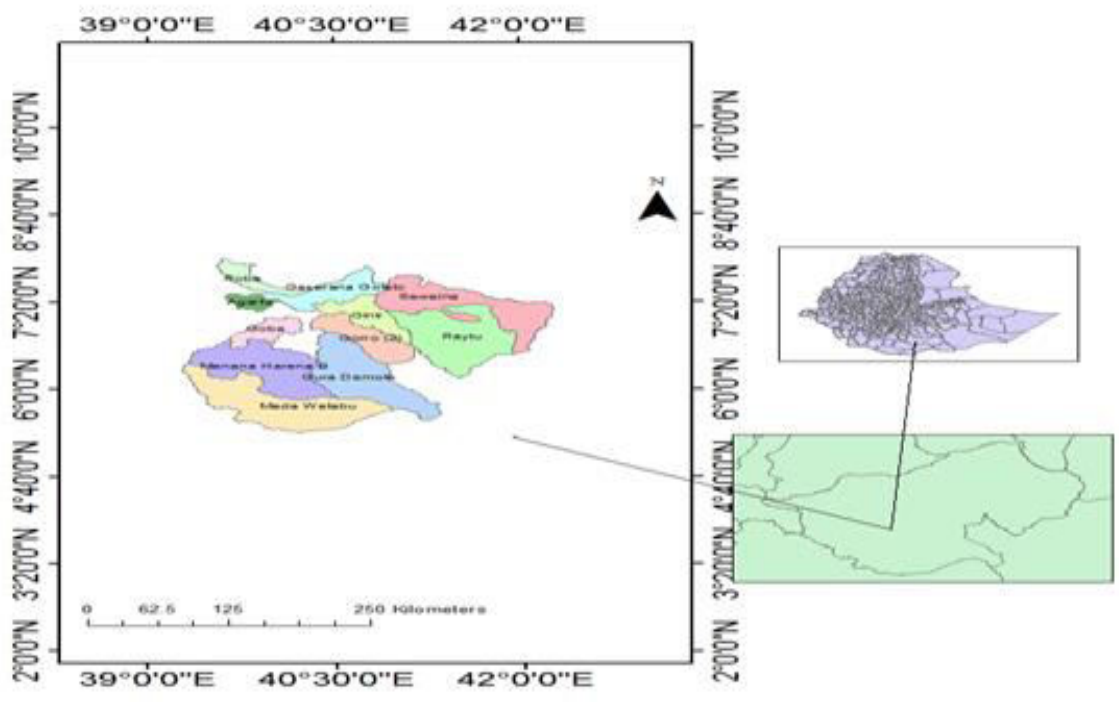

Fig 2: Map of the study area.

\section{MATERIALS AND METHODS}

In order to fulfill the research objectives, it is important to design that the data collected to be both accurate and relevant. Since this study attempts to investigate the impact of employees' turnover on organizational performance, a descriptive design approach was used in this study. In the data sources, the study used both the primary (questionnaires and in-depth interview) and secondary data sources. Hence, for the primary data's, the researchers prepared and conduct semi structured interviews to department heads, school directors and personnel administration director of the university. A self-administered mix of Five Point Likert's Scale questionnaires (closed/open ended) was prepared and distributed to academic staff on duty and ten (10) voluntary exit academic staffs. Furthermore, for secondary data source the study used organization figures, reports, past research and statistics from the government agencies, journal to supplement the primary data.

\section{Study Population}

The study population includes 425 local academic staffs of Madda Walabu University on duty at Robe campus. The study population also includes ten (10) voluntary exit employees include from the total number of 59 staff those who have resigned in 2016 Academic year. The researchers know them in term of where they are currently working and live.

\section{Sampling Technique}

The study employed Purposive, Simple Random sampling and Convenience sampling techniques. First, the academic staffs of the university who are on duty identified purposefully. Moreover, recent name list of Academic staff taken from the University that used as a sampling frame for the study. Then, from the listing, Simple Random sampling procedure employed to identify the respondents for data collection. Furthermore, the study also selected ten (10) voluntary exit employees who resigned from 2010 to 2015 selected by convenient sampling techniques because 
the researcher knows them in term of where they are currently working and live. Therefore, getting them for interview by telephone and send questionnaires through email made practical.

\section{Sample Size Determination}

For Descriptive research design based on a simple random sampling, the sample size required calculated according to the following formula (Krejcie \& Morgan, 1970).

$$
\mathrm{s}=\frac{x^{2} N P(1-P)}{d^{2}(N-1)+x^{2} P(1-P) .}
$$

$s=$ required sample size. $X^{2}=$ the table value of chisquare for 1 degree of freedom (3.841),

$N=$ the population size (425), $P=$ the population proportion (assumed to be .50 ) and

$d=$ the degree of accuracy (.05).

$$
\begin{gathered}
\mathrm{s}=\frac{3.841 * 425 * 0.5(1-0.5)}{(0.05)^{2}(425-1)+3.841 * 0.5(1-0.5)} \\
=\frac{408.1063}{1.060+0.96}=\frac{408.1063}{2.02} \\
=202.03=202
\end{gathered}
$$

Accordingly, the study took $47.5 \%$ i.e. 202 sample from a total number of 425 academic staffs in the University and adding $10 \%$ i.e. 20 samples for the probability that individual not respond to the questionnaire we get a total sample size of 222academic staffs i.e. (52.24\%) from a total number of 425 academic staffs.

\section{Data Analysis}

This research employed both qualitative and quantitative research techniques to analyse the data. Quantitative data analysis carried out using graphs, tables', frequencies distribution, and percentages, descriptive statistics, time series analysis and regressions analysis of Statistical package of Social Science (SPSS) software to determine the effect of turnover on organizational performance. Time series arise as recordings of processes, which vary over time. The main goal of a time series analysis used to analyze the trend of employees' turn over across years (20102015). Hence, its importance to use correlation to understand trends over time. The information obtains through interviews reported through narrative descriptions to complement those that collected through questionnaire (Hossain et al., 2019). Finally, conclusions and recommendation presented based on research findings and preceding facts.

\section{Validity \& reliability of data collection instruments}

Furthermore, the validity of the instruments was assured with the help of pilot testing by taking $10 \%$ (i.e. 20) sample respondents. In addition to this, to avoid non return questionnaires by engaging adequate enumerators. In order to assure the reliability data collected with different instruments was crosschecked. Accordingly, data collected through questionnaire, field observation and interview was triangulated. Moreover, the Purpose of the study clearly explained to respondents and data collected from the respondents based on their consent and their names and responses kept confidential, organization requested formally through official letter. Furthermore, this study carried out original research work and acknowledges all sources of materials dearly.

\section{RESULTS AND DISCUSSION}

\section{Characteristics of the Study Population}

As shown in Table 1 below, $88.30 \%$ of respondents participated in this study were male employees and the remaining $11.70 \%$ of respondents were female employees. Furthermore, the majority of respondents $107(48.20 \%)$ and $55.4 \%$ of the respondents who participated in this study were between the ages 20-29 years old and Married in their marital status, respectively.

In educational status, the majority $(65.3 \%)$ of employees have a Master's degree in their Education level, few (1.8\%) of these employees have $\mathrm{PhD}$ their highest qualifications and the remaining with a reasonable number (32.9\%) in possession of Bachelor's degrees. Given the varied the position or title of experts the largest proportion of the respondents $(96.8 \%)$ were lecturers followed by $3.2 \%$ of Asst. Professor. So as to analyze the cause and effects of stuff turnover employees whether Madda Walabu University is their first employer organization or not and duration of services is captured as the results displayed in the Table 1 below. 
Table 1: Demographic characteristics of the Study Population.

\begin{tabular}{|c|c|c|c|}
\hline Variable & Responses & Count & $\mathbf{N} \%$ \\
\hline \multirow{3}{*}{ Sex } & Male & 196 & 88.3 \\
\hline & Female & 26 & 11.7 \\
\hline & Total & 222 & 100.0 \\
\hline \multirow[t]{4}{*}{ Age } & $20-29$ & 107 & 48.2 \\
\hline & $30-39$ & 92 & 41.4 \\
\hline & $40-49$ & 23 & 10.4 \\
\hline & Total & 222 & 100.0 \\
\hline \multirow[t]{3}{*}{ Marital Status } & Single & 99 & 44.6 \\
\hline & Married & 123 & 55.4 \\
\hline & Total & 222 & 100.0 \\
\hline \multirow[t]{4}{*}{ Education Level of Expert } & Degree & 73 & $32.9 \%$ \\
\hline & Masters & 145 & $65.3 \%$ \\
\hline & $\mathrm{PhD}$ & 4 & $1.8 \%$ \\
\hline & Total & 222 & $100.0 \%$ \\
\hline \multirow[t]{3}{*}{ Position or Title } & Lecturer & 215 & 96.8 \\
\hline & Ass. professor & 7 & 3.2 \\
\hline & Total & 222 & 100.0 \\
\hline \multirow[t]{3}{*}{ Is $M W U$ your first employer } & Yes & 189 & 85.1 \\
\hline & No & 33 & 14.9 \\
\hline & Total & 222 & 100.0 \\
\hline \multirow{5}{*}{$\begin{array}{l}\text { For how many years you have been } \\
\text { in } M W U\end{array}$} & $0-2$ & 54 & 24.3 \\
\hline & $3-5$ & 85 & 38.3 \\
\hline & $6-8$ & 63 & 28.4 \\
\hline & 9 and above & 20 & 9.0 \\
\hline & Total & 222 & 100.0 \\
\hline
\end{tabular}

Source: Own survey, 2016

Source: Own survey, 2016

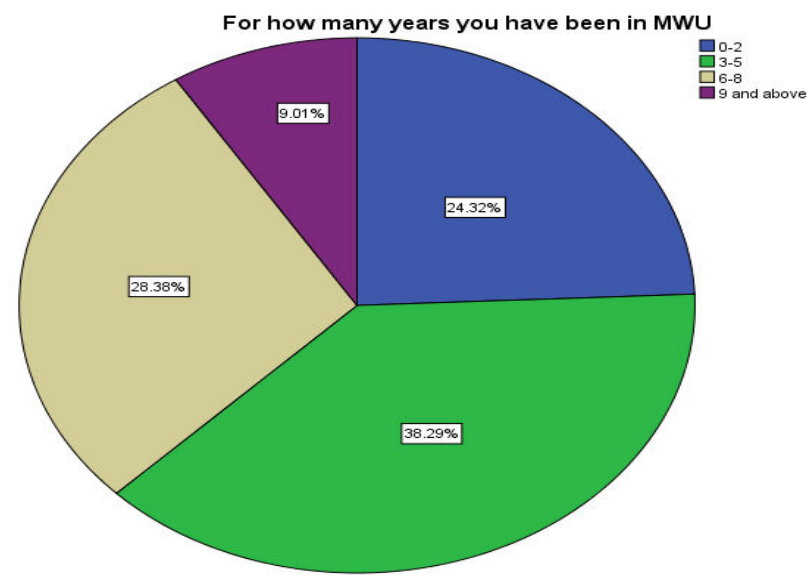

Fig 3: Length of Service of Respondents (In Percent).

Accordingly, $85.1 \%$ of the respondents replied that Madda Walabu University as their first employer organization. Few 14.9 percentage respondents had been working in other Organization previously. Furthermore, most of the respondents replied that they leaved their previous organization due to better salary, and high future educational chances, followed by health condition, harsh climatic aspects, and remoteness of the work areas. Given the varied number of years in service at the university, the UniversePG I www.universepg.com proportion of employees with service (3 up to 5years services) accounts $38.29 \%$ which is higher than that of employees with few years of service (less than 2 and 9 and above years).

Major Factors that lead to turnover in Madda Walabu University - The reliability of an instrument refers to its ability to produce consistent and stable measurements. The study conducted a pilot and the results are presented in Table 2 below. The findings 
of the study in Table 2 indicated that Employees turnover causes had a coefficient of 0.80 , Turnover Retention had a coefficient of 0.94, and Employees turnover Effects had a coefficient of 0.95. All variables depicted that the value of Cronbach's Alpha is above value of 0.7 thus. The total numbers of respondents who participated in this study and satisfactorily completed the questionnaire were 222, which is $100 \%$ response rate. Furthermore, Mean and Standard Deviation has been employed to analyses the ten possible causes of turnover of Academic staff of the organization. The descriptive table result clearly shows on average most of respondents perceived causes of turnover on organizational performance. As we can see, from the possible causes of questions in the category, majority score above three scales (as described in Table 2 - the mean index of cause 3.09) which implies the agreement level of participants in the study. Based on the result of inferential statistical analysis, the research found employee's turnover has a significant cause on performance of the organization.

Table 2: Reliability Test and Average Mean Index Statistics.

\begin{tabular}{lllll}
\hline \hline \hline No & Variable & C. Alpha & N & Number of items \\
1. & Employees turnover causes & 0.80 & 10 & Test Scale $=0.538 \quad$ mean $(*)$ \\
2 & Turnover Retention & 0.94 & 10 & Test Scale $=1.079$ mean $(*)$ \\
3 & Employees turnover Effects & 0.95 & 14 & Test Scale $=0.879$ mean $(*)$ \\
\hline \hline & Variable & Mean & $\mathbf{N}$ & \\
\hline \hline & Index of Causes & 3.09 & 222 & \\
& Index of Retention & 3.91 & 222 & \\
& Index of Effect & 4.07 & 222 & \\
\hline \hline
\end{tabular}

* Unstandardized items

Table 3: Mean and Standard deviation Summary of causes of Turnover on organization.

\begin{tabular}{|c|c|c|c|c|}
\hline Causes of Organizational Turnover & $\mathbf{N}$ & Mean & Std. Deviation & Mean Rank \\
\hline In my organization there is no opportunity for career advancement & 215 & 3.85 & 1.194 & 2nd \\
\hline I am not involved in decision making & 215 & 3.47 & 1.497 & $4 \mathrm{rt}$ \\
\hline Work burden is the cause of staff turnover & 215 & 3.36 & 1.506 & $5^{\text {th }}$ \\
\hline There is a lack of employee assistance programmes & 215 & 3.29 & 1.447 & $7^{\text {th }}$ \\
\hline I am satisfied with management support in work place & 215 & 2.17 & 1.286 & $<3.09$ \\
\hline Job training and career advancement are given in a fair manner & 215 & 2.15 & 1.263 & $<3.09$ \\
\hline I am satisfied with the salary $i$ am getting in my organization & 215 & 2.14 & 1.340 & $<3.09$ \\
\hline
\end{tabular}

Source: own survey, 2016

It could be noted from Table 3, high labour demand and job opportunities in the market, lack of opportunity for career advancement in the organization, unsatisfied with working condition and no involvement in decision-making, are the foremost causes of turnover of academic staff on organization performance. Working conditions include the organization of the work such as working hours, work schedules, work shifts, overtime, daily and weekly rest periods, emergency work, weekend work and holidays to mention just a few (Nel et al., 2004). Furthermore, Work burden as the cause of staff turnover, lack of appreciation of input and lack of employee assistance programmes are the next foremost causes of turnover on organization performance.

The Availability of Retention Strategies Adopted in the University - Concerning retention strategies, respondents were provided ten possible employees 
retention strategies opinion responses. Among the attitudinal questions raised for the respondents in this study includes employees must be recognized when they achieve goals, establish a reward system, employees feel Valued, work relationship between employees, employee must be paid well, provide positive working environment, establish a series of values as the basis for organizational culture and do organizations have develop specific competencies provide performance feedback and design an individualized career development plan to reduce turnover.

Table 4: Descriptive result of Employees Turnover Retention Strategies Aspects.

\begin{tabular}{|c|c|c|c|}
\hline Variable & Responses & Count & $\mathbf{N} \%$ \\
\hline \multirow{6}{*}{$\begin{array}{l}\text { Employees must be recognized when they achieve } \\
\text { goals. }\end{array}$} & Strongly Disagree & 20 & $9.0 \%$ \\
\hline & Disagree & 16 & $7.2 \%$ \\
\hline & Neutral & 24 & $10.8 \%$ \\
\hline & Agree & 54 & $24.3 \%$ \\
\hline & Strongly Agree & 108 & $48.6 \%$ \\
\hline & Total & 222 & $100.0 \%$ \\
\hline \multirow[t]{6}{*}{ Establish a reward system for long term services } & Strongly Disagree & 12 & $5.4 \%$ \\
\hline & Disagree & 20 & $9.0 \%$ \\
\hline & Neutral & 31 & $14.0 \%$ \\
\hline & Agree & 71 & $32.0 \%$ \\
\hline & Strongly Agree & 88 & $39.6 \%$ \\
\hline & Total & 222 & $100.0 \%$ \\
\hline \multirow{6}{*}{$\begin{array}{l}\text { Develop specific competencies, provide performance } \\
\text { feedback and design an individualized career } \\
\text { development plan }\end{array}$} & Strongly Disagree & 28 & $12.6 \%$ \\
\hline & Disagree & 10 & $4.5 \%$ \\
\hline & Neutral & 25 & $11.3 \%$ \\
\hline & Agree & 66 & $29.7 \%$ \\
\hline & Strongly Agree & 93 & $41.9 \%$ \\
\hline & Total & 222 & $100.0 \%$ \\
\hline \multirow[t]{6}{*}{ Employees Feel Valued } & Strongly Disagree & 27 & $12.2 \%$ \\
\hline & Disagree & 13 & $5.9 \%$ \\
\hline & Neutral & 23 & $10.4 \%$ \\
\hline & Agree & 39 & $17.6 \%$ \\
\hline & Strongly Agree & 120 & $54.1 \%$ \\
\hline & Total & 222 & $100.0 \%$ \\
\hline \multirow{6}{*}{$\begin{array}{l}\text { Work relationship between employees must be } \\
\text { improved }\end{array}$} & Strongly Disagree & 20 & $9.0 \%$ \\
\hline & Disagree & 17 & $7.7 \%$ \\
\hline & Neutral & 28 & $12.6 \%$ \\
\hline & Agree & 52 & $23.4 \%$ \\
\hline & Strongly Agree & 105 & $47.3 \%$ \\
\hline & Total & 222 & $100.0 \%$ \\
\hline \multirow{6}{*}{$\begin{array}{l}\text { Provide employees with a way to balance the } \\
\text { professional and personal aspects of their lives }\end{array}$} & Strongly Disagree & 19 & $8.6 \%$ \\
\hline & Disagree & 12 & $5.4 \%$ \\
\hline & Neutral & 39 & $17.6 \%$ \\
\hline & Agree & 76 & $34.2 \%$ \\
\hline & Strongly Agree & 76 & $34.2 \%$ \\
\hline & Total & 222 & $100.0 \%$ \\
\hline
\end{tabular}

Source: own survey, 2016

UniversePG I www.universepg.com 
Table 4 above highlights that, a total of $72.53 \%$ $(48.2 \%+24.33 \%)$ of respondents strongly agreed and agreed that employees must be recognized when they achieve goals followed by a total 71.62 \% $(32.0 \%+39.6 \% \%)$ of respondents strongly agreed and agreed that have to establish a reward system for long term services. The table above also revealed that, two employees retention strategies opinion score similar $71.62 \%$ responses lies in the Agree \& Strongly agree criteria i.e. organizations have develop specific competencies, provide performance feedback and design an individualized career development and making employees feel valued will contribute to enhance retention capacity of Universities and increase their willingness to stay long in their organizations. Moreover, a total of $70.72 \%$ $(23.4+47.3)$ of respondents agreed and strongly agree that working relationship between employees must be improved, followed by 152(68.4\%) provide employees with a way to balance the professional and personal aspects of their lives. Therefore, professional personal aspect balance is positively associated in retaining employees for long period of time rather than turnover decision.

\section{The Impact of Staff Turnover on the Organization} Performance - Furthermore, Mean and Standard Deviation has been employed to analyses the Impact of Staff Turnover on the Organization Performance. The descriptive table result clearly shows on average most of respondents perceived impacts of turnover on organizational performance. As we can see, from the possible impacts of questions in the category, the majority score above 4 scales (as described in Table 2 - the mean index of Impact 4.07) which implies the agreement level of participants in the study. Based on the result of inferential statistical analysis, the research found employee's turnover has a significant impact on performance of the organization.

Table 5: Mean and Standard deviation Summary of Turnover Impact on the organization.

\begin{tabular}{|l|l|l|l|c|}
\hline \multicolumn{1}{|c|}{ Impact of Staff Turnover on the Organization Performance } & N & Mean & $\begin{array}{c}\text { Std. } \\
\text { Dev }\end{array}$ & $\begin{array}{c}\text { Mean } \\
\text { Rank }\end{array}$ \\
\hline It causes in loss of some of the very experienced and skilled employees & 222 & 4.25 & 1.247 & 1 st \\
\hline High staff turnover causes reduction in work productivity. & 222 & 4.21 & 1.253 & 2 nd \\
\hline High staff turnover causes reduction in the quality of services rendered. & 222 & 4.16 & 1.142 & $3 \mathrm{rd}$ \\
\hline High staff turnover causes too much wastage of resources when new staff & 222 & 4.16 & 1.307 & 4 th \\
\hline It cause in lose public confidence in the operation of the organization & 222 & 4.13 & 1.288 & 5 th \\
\hline High staff turnover breaks team work within the organization. & 222 & 4.04 & 1.304 & 6 \\
\hline Employees tend not to give off their best at the workplace & 222 & 4.02 & 1.267 & 7 \\
\hline High staff turnover increasing work stress to present workers. & 222 & 4.01 & 1.251 & 8 \\
\hline Employees spend too much time in training new staff member. & 222 & 4.00 & 1.301 & 9 \\
\hline High staff turnover cause employee not to meet their deadlines. & 222 & 3.98 & 1.153 & 10 \\
\hline Staff turnover disrupts service delivery. & 222 & 3.97 & 1.173 & 11 \\
\hline Staff turnover causes a decline in services provision. & 222 & 3.96 & 1.161 & 12 \\
\hline High staff turnover increases work load for each employee. & 222 & 3.91 & 1.216 & 13 \\
\hline Staff turnover results in loss of customers. & 222 & 3.80 & 1.225 & 14 \\
\hline
\end{tabular}

Source: own survey, 2016

It could be noted from Table 5 above, loss of some of the very experienced and skilled employees, reduction in work productivity, reduction in the quality of services rendered, causes too much wastage of resources when new staff settles and lose public confidence in the operation of the organization are the foremost Impact of Staff Turnover on the UniversePG I www.universepg.com
Organization Performance. Furthermore, breaks team work within the organization, tend not to give off their best at the workplace, spending too much time in training new staff member, increasing work stress to present workers and spending too much time in training new staff member are the next foremost impact of staff turnover on the organization 
performance. Whereas, employee not to meet their deadlines, interrupting service delivery, a decline in services provision, increasing work load for each employee and loss of customers are the least Impact of Staff Turnover on the Organization Performance.
Inferential Statistical Analysis Result on Effect of Employee Turnover - Furthermore, the result of employee's turnover causes, retention strategies and staff turnover effects on performance of organization analyzed after aggregation of all the subscales of the three variables. Besides we analyses their pair wise correlation matrix.

Table 6: Pearson Correlation Analysis.

\begin{tabular}{|c|c|c|c|c|}
\hline & & Causes & Retention & Effect \\
\hline \multirow{2}{*}{ Causes } & Pearson Correlation & 1 & $0.88 * * *$ & $0.501^{* *}$ \\
\hline & Sig. (2-tailed) & & 0.000 & 0.000 \\
\hline \multirow{2}{*}{ Retention } & Pearson Correlation & $0.88 * * *$ & 1 & $0.479^{* *}$ \\
\hline & Sig. (2-tailed) & 0.000 & & 0.000 \\
\hline \multirow{2}{*}{ Effect } & Pearson Correlation & $0.501^{* *}$ & $0.479^{* *}$ & 1 \\
\hline & Sig. (2-tailed) & 0.000 & 0.000 & \\
\hline
\end{tabular}

Source: Own Survey 2016

Table 7: Multiple Linear Regression Analysis.

\begin{tabular}{|c|c|c|c|c|c|c|c|}
\hline \multirow{5}{*}{ Model Summary } & Source & SS & df & MS & $F(4,218)$ & $=$ & 587.38 \\
\hline & Model & 3594.486 & 4 & 898.6216 & Prob > F & $=$ & 0.000 \\
\hline & Residual & 333.5136 & 218 & 1.529879 & R-squared & $=$ & 0.9151 \\
\hline & & & & & Adj R-squared & $=$ & 0.9135 \\
\hline & Total & 3928 & 222 & 17.69369 & Root MSE & $=$ & 1.2369 \\
\hline Turnover Effect & \multicolumn{7}{|c|}{ Dependent Variable) } \\
\hline Turnover Causes & & Coef. & Std. Err. & $\mathrm{t}$ & $\mathrm{P}>\mathrm{t}$ & \multicolumn{2}{|c|}{ [95\% Conf. Interval] } \\
\hline & Disagree & 3.965517 & 0.229683 & 17.27 & 0.000 & 3.512833 & 4.418201 \\
\hline & Neutral & 4.077586 & 0.114842 & 35.51 & 0.000 & 3.851244 & 4.303928 \\
\hline & Agreed & 4.15942 & 0.148903 & 27.93 & 0.000 & 3.865946 & 4.452894 \\
\hline & Strongly Agree & 4.000 & 1.236883 & 3.23 & 0.001 & 1.562221 & 6.437779 \\
\hline & Constant & 3.571429 & 0.400976 & 8.91 & 0.000 & 2.781122 & 4.361735 \\
\hline
\end{tabular}

Note: Turnover Causes $=1$ (Strongly Disagree) is used as a base level

The study sought to establish the association between the study variables. The study findings indicated that perception towards causes and Retention strategies and effects of Employee turnover were positively associated with effect of turnover on organizational performance as represented by positive Pearson coefficients of 0.51 and 0.47 , respectively. Furthermore, the results revealed that the association between these predictor variables and employee performance was significant since their respective level of significance was less than $5 \%$ level of significance. The study findings imply that an increase or improvement in any of the predictor variables is UniversePG I www.universepg.com associated with an increase or improvement in performance. Furthermore, MLR were the econometric methods that used in the study to analyze the effect of employee turnover on organizational performance.

Multiple linear regressions were employed to investigate whether employee turnover causes are the factors affecting the performance of the organizations in Madda Walabu University. Based on the MLR model outputs the four turnover causes level and constant (excluding the base strongly disagree) having positive sign. Which indicate the negative effect of employee turnover on performance effect? The results in Table 7 revealed the independent variable affect the 
performance of organization with respect to individual perception level index of employee turnover effects subscale. The adjusted $\mathrm{R}^{2}$ indicates that about $92 \%$ of the variation in performance of the organization was attributed to employees turnover causes level. This true because of the $F(4,218)=587$ is found statistically significant at $(\mathrm{p}<0.05)$ level, which indicate the significance of the model overall explanation and fitness level. As the result reveals there is positive effect of employee turnover causes perception level and their thought towards the effect on organizational performance.

\section{The Trend of Employees' Turn over Across Years}

According to the interview held with human resource and department heads of the University, the number of Academic staff turnover is increasing from 2010 to 2015 G.C as the number of Academic staff who leave the institution as illustrated in the Fig $\mathbf{4}$ below.

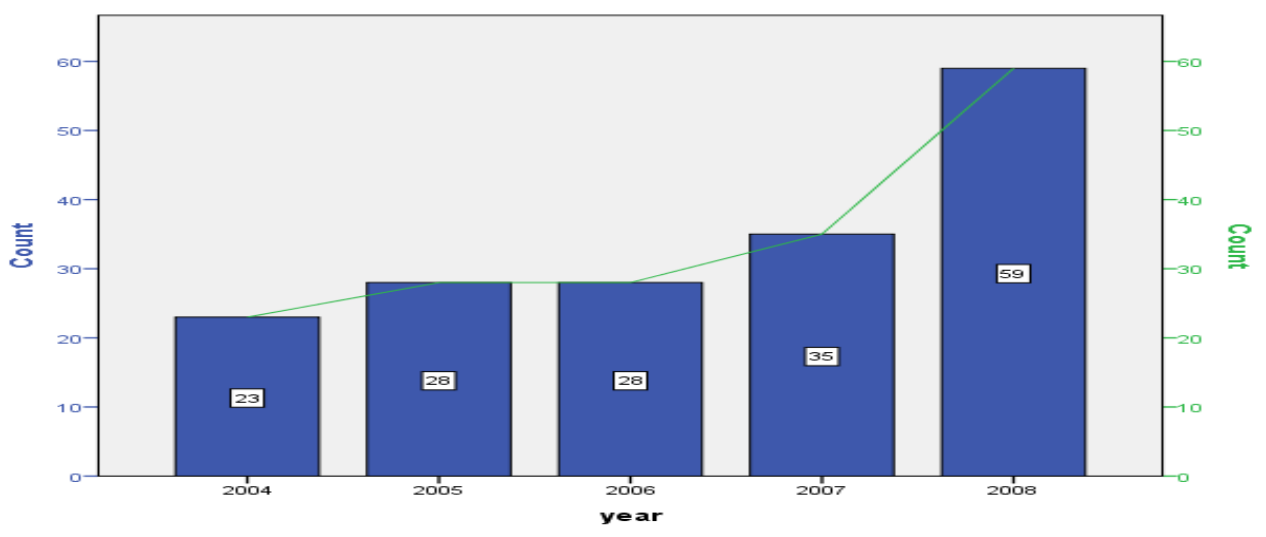

Fig 4: Trends of Academic Staff Turn Over Across Year (2010-2015)

Furthermore, respondents also asked about the existence and the trends of employees' turn over in organization. accordingly, almost all, 207 respondents about $93.2 \%$ concur to be witness for the existence of employees' turnover of which more than half 118 respondents, about 57\% confirmed the increasing trends of employees' turn over. This implies that there is an increasing trend of employees' turn over existence that results a significant impacts on the university.

\section{CONCULISION AND RECOMMENDATIONS}

This chapter covered the conclusion and recommendations of the study findings and suggestions for further study on areas not covered by this study were also included.

\section{CONCLUSION}

This section focuses on the conclusion of the study. The main aim of this study was to investigate the impact of staff turnover on organizational effectiveness and performance. It is noted that staff turnover has a negative impact on the organizational

UniversePG I www.universepg.com performance. The survey method was employed in this research due to homogeneity of respondents. The personal method of data collection was used to administer the questionnaires to all 222 respondents from 10 Schools and 37 course teams in Madda Walabu University and a high response rate of $100 \%$ was obtained. Based on the findings, most of the respondents agreed that high labour demand and job opportunities in the market, lack of opportunity for career advancement in the organization, Unsatisfied with working condition and no involvement in decision making, are the foremost causes of turnover of academic staff on organization performance followed by Work burden as the cause of staff turnover, lack of appreciation of input and lack of employee assistance programmes. The findings of this study also identified the university's retention strategies as appreciation of employees, make employees feel valued, smooth work relationship, and establish good reward system. With respect to the trends of employees' turn over the finding conclude that there is an increasing trend of employees' turn over in the university that results a significant impact on the university performance. With regard to the 
impact of Staff turnover on university's performance, majority of the respondents agreed that loss of very experienced employees, reduction in work productivity and quality of services rendering, too much wastage of resources and lose public confidence in the operation are the foremost Impact of Staff Turnover on the Organization Performance followed by breaking team work within the organization, tend not to give off their best at the workplace, spending too much time in training new staff member, increasing work stress to present workers. Hence, the study therefore makes recommendations arising from the empirical analysis, to reduce staff turnover in MWU.

\section{RECOMMENDATION}

Based on the findings of descriptive and inferential statistical analysis, the following recommendations in terms of statistically significant turnover major factors, variables of Employees Retention strategies and high staff turnover impact were forwarded. Besides the researcher tried to relate the recommendations with National Education and Higher Education institution Academic staff Development programs (HESP, HERQA and TDP) objectives. Since the study concludes that academic staff of the university perceived insufficient salary, poor working condition, unfair training and development program, low appreciation, lack of employee assistance program, high labour demand and job opportunities in the market. Therefore, MoE, the Board of management and the university ought to revisit career advancement and job training component of the university strategic plan and modify the university level implementation strategy and the respective state higher education institutions' ministry office should consider the salary and financial benefit program in university's teachers in near future.

Since trends of staff turnover shows an increasing trend, the university and $\mathrm{MoE}$ should incorporate new and updated way outs to minimize the current Lecturers flow from universities to Non-governmental organizations and private sector. In order to return back the reduced university's capacity in terms of national attrition rates, higher education access target, quality education assurance, significant community UniversePG I www.universepg.com and technology transfer and standardized researchbased problem-solving culture due to staff turnover. Besides University level top management, Board and higher-level sectoral advisors and planners have to start and prioritize the academic, personal, social and economic needs of university academic staff to control turnover and effectively implement education sector change and quality assurance tools (like cooperative education and organized education development soldiers of Students and teachers).

\section{ACKNOWLEDGEMENT}

We would like to express our deep and heartfelt thanks to almighty God for his help throughout our works for the accomplishments of this research paper. Our great appreciation goes to Department Head, Lecturers and human resource officers of Madda Walabu University. We would also like to thanks to all respondents and individuals who put a great valuable effort without which it is not possible to prepare this research paper.

\section{CONFLICT OF INTEREST}

The author declares that there is no conflict of interest.

\section{REFERENCES}

1) Altbach P. G. (2006). Comparative Higher Education: Knowledge and Development. Boston: Boston College, Chestnut Hill, Massachusetts.

2) Ayalew Shibeshi, (2007). Academic freedom in Ethiopia: Perspectives of Teaching Personnel, the case of Bahir Dar University, Forum for Social Studies, Addis Ababa, Ethiopia, pp. 137-177.

3) Brook Lemma. (2007). Academic freedom in Ethiopia: Perspectives of Teaching Personnel, the case of Haramaya University, Forum for Social Studies, Addis Ababa, Ethiopia, pp. 180-206.

https://www.africabib.org/rec.php?RID=317537 $\underline{849}$

4) Carrel M.R., Elbert, N.F. Hatfield, R.D., Grobler, P.A., Max, M. and Van der Schyf, S. (2000). Human Resource Management in South Africa. Cape Town: University Press., pp. 99-136. 
5) Demissu Gemeda. (2007). Academic freedom in Ethiopia: Perspectives of Teaching Personnel, the case of Addis Ababa Dar University, Forum for Social Studies, a Gemeda Adis Ababa, Ethiopia, pp. 65-97,

6) Habtamu Wondimu. (2007). Academic freedom in Ethiopia: Perspectives of Teaching Personnel, the case of Gondar Dar University, Forum for Social Studies, Addis Ababa, Ethiopia, pp. 357-385.

7) Hailu et al. (2013). Turn-over rate of academic faculty at the College of Health Sciences, Addis Ababa University: a 20-year analysis (1991 to 2011). Human Resources for Health, 11(1): 61.

https://doi.org/10.1186/1478-4491-11-61

8) Hammermesh D. and A. Rees. (1984). The Economics of Work and Pay. New York, pp. 99-136.

9) Henry, (2007). A review of literature on employee turnover. African Journal of Business Management, 1(3), 49-54. https://academicjournals.org/journal/AJBM/artic le-full-text-pdf/E2DA02016522

10) Hossain MR, Khatun S, and Rashid MA. (2019). Present status of information and internet services in union council of Madhukhali upazila: a case study, Br. J. Arts Humanit., 1(6), 35-44. https://doi.org/10.34104/bjah.019.35044

11) Krejcie R. V., \& Morgan, D. W. (1970). Determining sample size for research activities. Educational and Psychological Measurement, 30, 607-610. https://doi.org/10.1177/001316447003000308

12) Mathis R, L., and Jackson J.H., (2006) Human Resource Management $12^{\text {th }}$ Edition, Mason, USA.
13) Minister of education (MoE), (2003). Higher Education Proclamations No.351/2003 and No. 650/2009 in Ethiopia.

14) Muhammad Naeem Tariq, Muhammad Ramzan Aisha Riaz (2013). The Impact of Employee Turnover on the Efficiency of the Organization. Interdisciplinary Journal of Contemporary Research in Business, 4(9): 700-711. https://journal-archieves27.webs.com/ 700-711.pdf

15) Nel P.S., Van Dyk, P.S., Haasbroek, G.D., Schulltz, H.B., Sono, T. and Werner, A. (2004). Human Resources Management. $6^{\text {th }}$ Edition. Cape Town: Oxford University Press.

16) Ngirwa C. (2005). HRM in African Work Organisations, 1, 19-36.

17) Stromquist N. (2007). The Academic Profession in the Globalization Age: key trends, Challenges and Possibilities, Higher Education in the New Country. Boston: Boston College.

18) Tesfaye Tadesse, (2007). Academic freedom in Ethiopia: Perspectives of Teaching Personnel, the case of Jimma Dar University, Forum for Social Studies, Addis Ababa, Ethiopia, pp. 207-252,

19) Teshome Yizengaw. (2007). The Ethiopian Higher Education: Creating Space for Reform. St. Mary's UC Printing Press. pp. 107

20) Ubagu MM, and Gbuushi JA. (2020). Perceived effect of motivation on the job performance of library personnel of universities in Benue state, Nigeria, Br. J. Arts Humanit., 2(1), 14-23. https://doi.org/10.34104/bjah.020014023

21) Wana Leka. (2007). Academic freedom in Ethiopia: Perspectives of Teaching Personnel, the case of Arbaminch Dar University, Forum for Social Studies, Addis Ababa, Ethiopia, pp. 99-136.

Citation: Taye D. and Getnet B. (2020). The impact of employee turnover on organizational performance: a case study of Mada Walabu University, Bale Robe, Ethiopia. Am. J. Pure Appl. Sci., 2(3), 51-63.

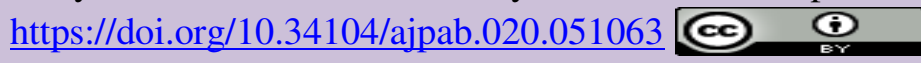

